\title{
ANALYZING THE EFFECTS OF INDIVIDUAL COMPETENCIES ON PERFORMANCE: A FIELD STUDY IN SERVICES INDUSTRIES IN TURKEY
}

\author{
* Halil Zaim \\ **Mehmet Fatih Yaşar \\ $* * *$ Ömer Faruk Ünal \\ *Fatih University, Turkey \\ **Nigerian Turkish Nile University, Nigeria \\ ***Süleyman Demirel University, Turkey
}

\begin{abstract}
This study aims to analyze the effects of individual competencies on performance in the services industries in Turkey. A survey research was conducted in this study. The survey was addressed to the companies in service sector in Turkey, and the questionnaires have been distributed to 3000 employees in 30 companies and 2679 completed questionnaires were returned, representing a response rate of 89 percent. An exploratory factor analysis (EFA) was used to assess the influence of individual competencies on performance. The findings revealed that there is a positive relationship between competencies and individual performance. Furthermore, core competencies are appeared to have the most significant effect on individual performance. The results of this study provided some empirical evidences referring the effects of individual competencies on organizational performance. One of the most surprising results of the study is that, when it comes to organizational performance, managerial competencies appeared to be the most significant factor. The survey was not comprehensive to include all possible service sectors in Turkey. This research is limited to banking, cargo, communication, food and catering, finance, publishing, retail, IT, and tourism companies. Thus, the results cannot be generalized to other industrial sectors that were not part of this study. This study analyzes the impact of individual competencies on performance whether it is high or low. The qualitative approach of this study produces rich information about employee's competency and performance. The paper contains useful information for management practitioners about maintaining and increasing the individual competency to increase organizational performance.
\end{abstract}

Keywords: Individual Competencies, Performance, Service Industries, Turkey

\section{INTRODUCTION}

The rise of knowledge on economy and socio-economic transformation of the societies have led knowledge to be the fundamental means of wealth and prosperity (Drucker, 1993; Hope and Hope 1997; Bozbura, 2007). From the business perspective, knowledge seems to be a key factor for organizations' success in the long run (Mansell and When, 1998; Stewart, 2001; Tat and Hase, 2007). Due to that, leveraging the knowledge resources effectively and efficiently appears to be a vital issue in order to gain the competitive advantage and to ensure the sustainable development for the societies, as well as for the organizations (Nonaka, 1998; Davenport and Prusak, 1998; Storey and Barnett, 2000).

In the knowledge economies, there is a shift from task-based approaches to competency-based approaches. Therefore, the popularity of competency management systems has gained a special concern both from practitioners and academicians (Clardy, 2008). Competency management can contribute to organizations knowledge base and increase the knowledge utilization capability of an organization. Hence, it became an important research object in the more general area of knowledge management and is often integrated with learning management systems (Draganidis and Mentas, 2006). Recent studies in this field, clarified that individual competency management is an area of research attracting efforts to leverage personal development, knowledge generation (Abou-Zeid, 2002), development (Bhatt, 2000), sharing (Sveiby, 2001), 
and utilization (Bender and Fish, 2000), organizational learning, innovation and effectiveness (Malhotra, 2000). In addition to being regarded as a focal point for planning, organizing, integrating and improving all aspects of knowledge management and human resource development systems. Competency management modeling is also regarded as an approach focused on improving organizational performance.

The main objective of this study is to compose a useful individual competency model in services industries based on the "ranking model" of employee competencies, which consists of three major dimensions: core competencies, managerial competencies and functional (task-related) competencies (Stephen and Uhles, 2012).

Secondly, this study aimed to analyze the effects of aforementioned dimensions of competencies to individual and organizational performance. Based on the provided data, 2679 questionnaires collected from 30 different companies of services industries in Turkey. The data analysis indicate that, there is a positive linear correlation between aforesaid key dimensions of competencies and both individual and organizational performance.

\section{Literature Review}

\section{Definition}

The concept of "competency" is a confusing term and particularly mixed up with "skill". It is mainly because different terms have often been used interchangeably. From the management perspective, competencies are defined by two main streams: organizational or personal. Human Resource Management (HRM) literature focuses on the individual competencies. McClelland (1973) used the term as a symbol for an alternative approach to traditional intelligence testing. According to author, competence is a characteristic trait of a person that is related to superior performance and a demonstration of particular talents in practice and application of knowledge required to perform a job.

Boyatzis (2008) also analyzed managerial competencies and defined competencies as an underlying characteristic of a person that could be a motive, trait, skill, aspect of one's self-image, social role, or a body of knowledge which he or she uses. These characteristics are revealed in observable and identifiable patterns of behavior, related to job performance and usually include knowledge, skill and abilities. In another definition, competencies are specified as a mean of 'being able to perform a work role to a defined standard with reference to real working environments'.

It is generally seen as "a cluster of related knowledge, skills, and attitudes that affects a major part of one's job (a role or responsibility), that correlates with performance on the job, that can be measured against wellaccepted standards, and that can be improved via training and development" (Özçelik and Ferman, 2006). Dingle (1995), adds awareness to this definition. According to Dingle, competence is a combination of knowledge, skill and awareness. In this definition, knowledge refers to the understanding of fundamental principles required to accomplish the task in hand, skill refers to the application of this understanding and awareness refers to the proper application of skill, in accordance with professional and corporate "good practice".

In addition, Pate et.al (2003), distinguish individual competencies from the epistemological standpoint as rationalist and objectivist. From rationalist perspective, competence is a specific set of attributes used in performing a job. In rationalist perspective there is a distinction between job and worker. Thus, job oriented side of competence is associated with characteristics of high performing employee such as motives traits and social skills that can be learned through education, experience or vocational training. Task oriented aspect of competence, on the contrary, deals with the behavior of particular individuals and how they act in organizational environment. From the subjectivist perspective, worker and work are considered as one entity. Accordingly, competency is composed of a person's experiences and personality combined with job related factors that stem from formal and informal organization. Hence, this approach focuses on the interaction between the individual and the job, thereby, taking into account what the individual brings to the job and the characteristics of the job itself.

Moreover, there is an alternative to describe competencies on basis of outcomes that a competent individual should be able to achieve, and thus defining generic standards of performance for particular activities. This approach considers competencies as input and concentrates on the outcomes of competencies such as 
productivity, quality and decision making.

Alongside the HRM literature on competencies which focuses on employee, there is a parallel body of literature in strategic management (SM) that view competencies as characteristics of an organization as a whole, with particular emphasis on core competencies and dynamic capabilities. According to organizational perspective competencies belong to the organization and are embedded processes and structures that tend to reside within the organization, even when individuals leave (Cardy and Selvarajan, 2006).

At organizational level, "core competencies" give an organization strategic competitive advantage and can be defined as "a firm's strategic resources that reflect the collective learning in the organization". Core competencies refer to distinctive capabilities of an organization that describe excellence performance, contributes to customer value, and difficult to imitate including "the skills and abilities employees are expected to have or develop, as well as the processes required to achieve success" (Baker, et.al, 2009). Moreover, it is considered to be important at a firm's corporate level, which are the key for the firm's survival and are central for its strategy (Fleury, and Fleury, 2005). Dynamic Capability on the other hand, is "a company's capability to adjust its competences over time and is closely related to resources important for change".

From a holistic view competency is a combination of tacit and explicit, individual and collective knowledge, capability, behavior and skills that results in effectiveness, efficiency and superior performance. In other words it is the true applied knowledge and utilized capacity of an individual or an organization.

In our study we are going to focus on the individual competencies from the HRM perspective. However many scholars (Cardy, Selvarajan, 2006; Draganidis and Mentzas, 2006; Soderquist and Papalexandris, 2010) claim that there is a strong connection between individual and organizational competencies. It is mainly because; organizations have noticed that the ability and knowledge utilization of their workforce is the key to gain sustainable competitive advantage (Özçelik and Ferman, 2006). Furthermore, "the concept of competency lies at the heart of HRM, providing a basis for horizontal integration of key HR activities, such as selection, performance assessment, training, career development, and reward management, as well as vertical integration with organizational strategy, values, business processes and performance outcomes among others"( Soderquist and Papalexandris, 2010).

\section{Competency Models}

There is a variety of competency models referring to different aspects of competencies. A competency model is "a list of competencies which are derived from observing satisfactory or exceptional employee performance for a specific occupation" (Draganidis and Menzsaz, 2006) and used to categorize competencies for common use.

One of the dominant modeling of competencies is developing generic versus organization-specific competencies. Generic competencies is a cluster of competencies identified within the context of a specific job generically, i.e. common to all individuals occupying that specific job whereas, organization-specific competencies is a set of competencies specific to the job in a particular organization (Soderquist and Papalexandris, 2010). Generic competencies usually identified on trait-based or behavior-based (Cardy, Selvarajan, 2006).

Another famous modeling is ranking competencies according to managerial levels. In general, three categories are used in ranking model such as core competencies which is required from all employees, leadership/managerial competencies required from managerial positions and functional competencies required to be performed in a particular job role or profession (Özçelik and Ferman, 2006). In a similar ranking model Stephen and Uhles (2012) suggest three set of competencies for individual contributors, managers and executives.

In the organizational psychology literature, distinguishing contextual competencies from task competencies is also a common approach used in competency modeling. In this model, task competencies are job-specific and are associated with the technical functions of an organization such as organizing, planning, coordinating and controlling, whereas, contextual competencies are those discretionary job-related characteristics that informally contribute to organizational effectiveness but are not formally recognized as part of the job (Ahadzie, et.al, 2009). 
Tauron, classifies competency approaches into three categories from the assessment point of view. These are: research-based, strategy-based and value-based approaches. Researched-based approach is focusing on the behavior of the superior performers in the organization and can also be categorized as behavioral competencies. Strategy-based approach tries to identify competencies that link individual characteristics with organizations' strategic direction. Value-based approach underlines the cultural values of the organization hence considered to have strong motivating effect on individuals (Touron, 2009).

Competence iceberg model, on the other hand, divide competencies into two main categories, one upside water surface such as knowledge and skills and the other is below the surface that includes mainly viewpoint of value, self image, character/personality, self-force/social motivation and so on (Liu, et. al, 2005).

\section{Competency and Performance Relationship}

For the last few decades, competencies are often used for the basis of performance appraisal (Cardy and Selvarajan, 2006). The competencies, as a measurement tool, identify behavioral factors relevant to performance in the job and viewed as how the job is carried out. Hence many organizations use competency models as a part of their employee development program to appraise behavioral performance indicators together with objectives (Özçelik and Ferman, 2006). Accordingly, many scholars (McClelland, 1973, Levenson, et.al, 2006, Ryan, et.al., 2009) have claimed that assessment of employees' competencies provide an effective method for predicting job performance.

There is a variety of research that clarify the relationship between competencies and employees' job (task) performance (McClelland, 1973; Liu, 200; Dainty, 2004; Levenson, 2006; Ryan, et.al, 2009). For example, findings of Ahadzie et.al.'s (2009) study demonstrate the suitability and potential usefulness of their competency-based model that reflects elements of both performance behaviors and outcomes in predicting the performance. Similarly, there are other research (Ryan et.al, 2009; Spencer, et.al 2008) highlighting the validity and utility of competencies in predicting employees' work performance.

Furthermore, there are studies that indicate the affects of certain competencies on individual job performance. For example Qiao and Wang, (2009) suggest that team-building, communication; coordination, execution and continual learning are critical competencies for the success of middle managers in China. Likewise, there empirical evidences indicating the relationship between competencies such as HRM (Fleury and Fleury 2005; Liu, et.al, 2005; Collings, et.al 2010, Anwar, et.al, 2012), leadership (Clark and Armit, 2010; Asree, et. al, 2010; Pereira and Gomez, 2012).

The relationship between individual competencies and organizational performance is also stated. However, there are less empirical evidences found in this issue (Levenson, et.al, 2006, Ryan, et.al. 2009; Gammie and Joyce, 2009).

On the other side, despite the increasing tendency in using competency models, there are still some confusion and skepticism about the relation between competencies and performance. These are mainly because of the difficulties in assessment of competencies (Currie and Darby, 1995) and the complex and lengthy process required for identifying the appropriate competency performance relationship (Vakola, et. al., 2007). In addition to that organizational performance has many dimensions, yet it is not easy to connect individual competencies to organizational performance (Liu, et. al., 2005; Vakola et.al. 2007).

\section{Research Methodology}

\section{Survey Instrument}

The survey instrument is composed of questions relating to employee competencies and performance. The conceptual definition of competency construct was derived from the literature, and survey work was adopted from Berdrow and Evers (2009). They developed the "Bases of Competence Model" which is a multi-item scale to reveal the main factors of employee competencies. The performance variable is derived from the study of Zaim and Koçak (2010). The questionnaire was progressed by discussing with a panel of experts and academicians and finalized with the study of Zaim (2012). A five-point Likert scale was used for each of the 5 questions, scored from 1 to 5 where the number (1) means Strongly Disagree, (2) Disagree, (3) Neither Disagree or Agree, (4) Agree, and (5) Strongly Agree. 


\section{The Sample}

Data collected from service sector companies in Turkey. Service sector can be defined as "the portion of the economy that produces intangible goods". According to economic development stages of the countries, as income per capita rises, agriculture loses its primacy, giving way first to a rise in the industrial sector, then to the service sector. According to World Bank Report, these two consecutive shifts are called "industrialization" and "post-industrialization". Also, growing economies are likely to go through these stages. Particularly, service sector has emerged as the most dynamic and innovative sector in the last few decades for high-income countries. This reality for service sector dominates the economic growth and wealth production (Triplett and Bosworth, 2004).

On the other hand, service sector grows rapidly in the developing countries as well. However, providing the intellectual infrastructure and maintaining the well-educated, competent labor force is considered to be one of the most important challenges of the developing economies like Turkey.

Turkish economy has been undergoing an outstanding transformation since 2001. During this period, the share of agriculture in the economy decreased, while that of the service and manufacturing sectors expanded. Hence, increasing competencies of the labor force according to the rapidly changing demands of the global markets is considered as one of the major strategic objectives.

The sample was chosen among the leading companies of service sector. The research was conducted in various sectors ranging from banking, cargo, communication, food and catering, finance, publishing, retail, IT, and tourism sectors. The questionnaires have been distributed to 3000 employees in 30 different companies in service industry. A total of 2679 usable questionnaire were returned.

\section{Research Objectives and Hypotheses}

Based on the reviewed literature, this study proposes the "ranking model" of employee competencies which was composed of three main dimensions: core competencies, managerial competencies and functional (taskrelated) competencies (Stephen and Uhles, 2012). This study suggests that aforesaid factors have direct effects on organizational performance. According to the research framework, core competencies, managerial competencies and functional competencies' factors are assumed to influence the individual and organizational performance. This study will independently analyze the effects of those critical factors of competencies on individual and organizational performance.

The hypotheses underlying the impact of employee competencies on individual performance are:

$\mathrm{H}_{1}$ : Individual Performance improves if core competencies are enhanced.

$\mathrm{H}_{2}$ : Individual Performance improves if managerial competencies are enhanced.

$\mathrm{H}_{3}$ : Individual Performance improves if functional competencies are enhanced.

The following hypotheses are also proposed to state in underlying the impact of employee competencies on organizational performance.

$\mathrm{H}_{4}$ : Organizational Performance improves if core competencies are enhanced.

$\mathrm{H}_{5}$ : Organizational Performance improves if managerial competencies are enhanced.

$\mathrm{H}_{6}$ : Organizational Performance improves if functional competencies are enhanced.

\section{Analysis and Results}

The data analysis was conducted in three steps:

Performing an exploratory factor analysis (EFA) with varimax rotation to determine the underlying dimensions of employee satisfaction.

Measuring the direct impact of critical factors of employee satisfaction on the individual performance.

Measuring the direct impact of critical factors of employee satisfaction on commitment.

\section{Exploratory Factor Analysis (EFA)}

Due to potential, conceptual and statistical overlap, an attempt was made to produce parsimonious set of 
distinct non-overlapping variables from the full set of items underlying the construct. Exploratory factor analysis with varimax rotation was performed on the employee competencies criteria in order to extract the dimensions of the construct.

The EFA on the 23 employee competencies' items yielded in 3 factors with Eigen values, greater than 1 which was expected according to existing literature (Özçelik and Ferman, 2006). All items were loaded on these 3 factors. Based on the item loadings, these factors were respectively labeled as core competencies (C), managerial competencies $(\mathrm{M})$ and task competencies $(\mathrm{T})$. The Kaiser-Meyer-Olkin measure of sample adequacy was found as 0,94 , which supports the validity of EFA results. The Cronbach's alpha measures of reliability for the five factors were 0,92 for core competencies, 0,93 for managerial competencies and 0,91 for task competencies.

\section{Regression Analysis for Individual Performance}

As mentioned earlier, it is assumed that there is a positive linear relationship between critical factors of employee competencies and individual performance. In order to test the hypotheses, a linear model was constituted and a regression analysis was performed using "Ordinary Least Squares Estimates" technique. In the written formulation below, individual performance is dependent variable (Yp), although core competencies $(\mathrm{C})$, managerial competencies $(\mathrm{M})$, and task competencies $(\mathrm{T})$ are determined as independent variables respectively. In addition, prior to performing multiple regression analysis, all the assumption of linear regression was tested and no problem had occurred.

$\mathrm{Y}_{\mathrm{p}}=\beta_{0}+\beta_{1} \mathrm{C}+\beta_{2} \mathrm{M}+\beta_{3} \mathrm{~T}$

The next step is assessing the significance of the model using ANOVA (F) test. The significance level demonstrates the combined effects of all the independent variables in the regression model. As a general rule, significance level of the model for acceptance should be equal or less than $\% 5(0.05)$.

Furthermore, the adjusted $\mathrm{R}^{2}$ (coefficient of multiple determination) was found 0.62 for individual performance. Almost $62 \%$ of individual performance (dependent variable) can be explained by independent variables (competencies). The remaining $38 \%$ is estimated as the influence of personal evaluations, psychological and sociological influences, other performance indicators, and subjective evaluations which was not included in the model.

Table 1: Model Summary for Individual Performance

\begin{tabular}{|c|c|c|c|c|}
\hline Model & $\mathbf{R}$ & R Square & Adjusted R Square & Std. Error of the Estimate \\
\hline $\mathbf{1 , 0 0}$ & 0,79 & 0,62 & 0,62 & 0,50 \\
\hline $\mathbf{a}$ & $\begin{array}{c}\text { Predictors: (Constant), core, task } \\
\text { and managerial competencies }\end{array}$ & & & \\
\hline
\end{tabular}

Finally, using "t-test", partial regression coefficients which explain the effects of independent variables on the dependent variable were analyzed. As shown in Table 2, the standardized regression weights for all variables are significant at the 0.05 level. These results indicate that all hypotheses are significant at 0.05 levels.

Table 2: ANOVA (b) Test for Individual Performance

\begin{tabular}{|c|l|c|c|c|c|c|}
\hline Model & & $\begin{array}{c}\text { Sum of } \\
\text { Squares }\end{array}$ & df & $\begin{array}{c}\text { Mean } \\
\text { Square }\end{array}$ & F & Sig. \\
\hline $\mathbf{1 , 0 0}$ & Regression & 984,02 & 3,00 & 328,01 & $1.298,32$ & 0,00 \\
\hline & Residual & 606,33 & $2.400,00$ & 0,25 & & \\
\hline & Total & $1.590,35$ & $2.403,00$ & & & \\
\hline $\mathbf{a}$ & $\begin{array}{l}\text { Predictors: (Constant), core, task } \\
\text { and managerial competencies }\end{array}$ & & & & & \\
\hline $\mathbf{b}$ & $\begin{array}{l}\text { Dependent Variable: individual } \\
\text { performance }\end{array}$ & & & & & \\
\hline
\end{tabular}


Among the all factors, core competencies were found as most important criterion. It is followed by task competencies $(0,26)$ with the value of its standardized regression weight being $0.38(\mathrm{p}<0.01)$. Managerial competencies have less effect $(0,20)$ on individual performance in comparison with other two factors. However, all factors have positive linear correlation with individual performance.

Table 3: Regression Analysis for Performance

\begin{tabular}{|c|c|c|c|c|c|c|}
\hline \multicolumn{7}{|c|}{ Coefficients(a) } \\
\hline Model & & $\begin{array}{l}\text { Unstandardized } \\
\text { Coefficients }\end{array}$ & & $\begin{array}{c}\text { Standardized } \\
\text { Coefficients }\end{array}$ & $\mathbf{t}$ & Sig. \\
\hline & & B & $\begin{array}{l}\text { Std. } \\
\text { Error }\end{array}$ & Beta & B & $\begin{array}{l}\text { Std. } \\
\text { Error }\end{array}$ \\
\hline \multirow[t]{4}{*}{1,00} & (Constant) & 0,57 & 0,05 & & 10,69 & 0,00 \\
\hline & Core competencies & 0,39 & 0,02 & 0,38 & 16,44 & 0,00 \\
\hline & Managerial competencies & 0,19 & 0,02 & 0,20 & 8,26 & 0,00 \\
\hline & Task competencies & 0,27 & 0,02 & 0,26 & 11,73 & 0,00 \\
\hline $\mathbf{a}$ & $\begin{array}{l}\text { Dependent Variable: individual } \\
\text { performance }\end{array}$ & & & & & \\
\hline
\end{tabular}

\section{Regression Analysis for Organizational Performance}

The second regression analysis was conducted to test the relationship between competencies and organizational performance. In order to test the hypotheses, a linear model is constituted and a regression analysis was performed using "Ordinary Least Squares Estimates" technique. In the formulated model below, organizational performance is dependent variable (Yop); whereas core competencies (C), managerial competencies (M) and task competencies $(\mathrm{T})$ were determined as independent variables respectively. In addition, before performing multiple regression analysis, all the assumptions of linear regression were statistically tested and no problem was found.

$\mathbf{Y}_{\mathrm{op}}=\boldsymbol{\alpha}_{0}+\boldsymbol{\alpha}_{1} \mathbf{C}+\boldsymbol{\alpha}_{2} \mathbf{M}+\boldsymbol{\alpha}_{3} \mathbf{T}$

Subsequently, the following step is assessing the significance of the model using ANOVA (F) test, which demonstrates the collective effects of all independent variables in the regression model. In order to consider significance level of the model, significance level for acceptance should be equal or less than \%5 (0.05).

Furthermore, the adjusted $\mathrm{R}^{2}$ (coefficient of multiple determination) was found 0.45 . Employee competencies variable explain $45 \%$ of organizational performance (dependent variable). This result is consistent with the existing literature pertaining to organizational performance. Hence, there are many other factors that affect organizational performance and other employee competencies (Kaya, 2006).

Table 4: Model Summary of Organizational Performance

\begin{tabular}{|c|c|c|c|c|}
\hline Model & $\mathbf{R}$ & R Square & Adjusted R Square & Std. Error of the Estimate \\
\hline $\mathbf{1 , 0 0}$ & 0,67 & 0,45 & 0,45 & 0,64 \\
\hline $\mathbf{a}$ & $\begin{array}{c}\text { Predictors: (Constant), } \\
\text { core, task and managerial } \\
\text { competencies }\end{array}$ & & & \\
\hline
\end{tabular}

Finally, through "t-test", partial regression coefficients, which explain the effects of independent variables on dependent variable, were discretely analyzed. As shown in Table 5, the standardized regression weights for all variables are significant at the 0.05 level. The results indicate that all hypotheses were supported at 0.05 significance levels. 
Table 5: ANOVA Test of Organizational Performance

\begin{tabular}{|c|l|c|c|c|c|c|}
\hline Model & & Sum of Squares & df & Mean Square & F & Sig. \\
\hline $\mathbf{1 , 0 0}$ & Regression & 804,28 & 3,00 & 268,09 & 663,52 & 0,00 \\
\hline & Residual & 966,89 & $2.393,00$ & 0,40 & & \\
\hline & Total & $1.771,18$ & $2.396,00$ & & & \\
\hline $\mathbf{a}$ & $\begin{array}{l}\text { Predictors: (Constant), core, } \\
\text { task, managerial competencies }\end{array}$ & & & & & \\
\hline $\mathbf{b}$ & $\begin{array}{l}\text { Dependent Variable: } \\
\text { organizational performance }\end{array}$ & & & & & \\
\hline
\end{tabular}

The Table 6 illustrates the comparative effects of competencies on organizational performance. Predictably, managerial competencies have the most significant impact $(0.40)$ on organizational performance. Additionally, core competencies $(0.18)$ and task competencies $(0.14)$ are nearby.

Table 6: Regression Analysis for Organizational Performance

\begin{tabular}{|c|c|c|c|c|c|c|}
\hline Coefficient & & & & & & \\
\hline \multirow[t]{2}{*}{ Model } & & $\begin{array}{c}\text { Unstandardized } \\
\text { Coefficients }\end{array}$ & & $\begin{array}{c}\text { Standardized } \\
\text { Coefficients }\end{array}$ & $\mathbf{t}$ & Sig. \\
\hline & & B & Std. Error & Beta & B & Std. Error \\
\hline \multirow[t]{4}{*}{1,00} & (Constant) & 0,96 & 0,07 & & 14,35 & 0,00 \\
\hline & Core competencies & 0,20 & 0,03 & 0,18 & 6,52 & 0,00 \\
\hline & Managerial competencies & 0,39 & 0,03 & 0,40 & 13,68 & 0,00 \\
\hline & Task competencies & 0,15 & 0,03 & 0,14 & 5,11 & 0,00 \\
\hline $\mathbf{a}$ & $\begin{array}{l}\text { Dependent Variable: } \\
\text { organizational } \\
\text { performance }\end{array}$ & & & & & \\
\hline
\end{tabular}

\section{CONCLUSION}

In this study, the researchers proposed the "ranking model" of employee competencies which is composed of three main dimensions: core competencies, managerial competencies and functional (task-related) competencies (Stephen and Uhles, 2012). Consistent with the statistical analysis, abovementioned factors have direct influence on both individual and organizational performance. Recently, services sector has turned out to be one of the most flourishing sectors in Turkey.

Primarily, the researchers analyzed the relationship between individual competencies and individual performance. The research findings indicated that there is a positive relationship between competencies and individual performance. Furthermore, core competencies had utmost significant effect on individual performance.

Secondly, we analyzed the relationship between individual competencies and organizational performance. As mentioned earlier, empirical facts regarding the relationship between individual competencies and organizational performance are adequate in existing literature. The results of this study provided some empirical evidences concerning the effects of individual competencies on organizational performance. One of the most astonishing results of this study is that, when it comes to organizational performance, managerial competencies appeared to be the most significant factor.

Finally, this study's findings specified numerous critical points regarding the competencies and performance relationships. There are two key points for this study. At first, the present literature is focusing on developed (Western) countries.

From an academic perspective, this study analyzed the data from a particularly developing country, Turkey. Moreover, this study provided the analysis of the services sector, which has been neglected in Turkey in terms of competency studies. Hence, the results demonstrate that competencies in services sector play an important role for both individual and organizational performance. 
Journal of Global Strategic Management | V. 7 | N. 2 | 2013-December | isma.info | 67-77 | DOI: 10.20460/JGSM.2013715668

As a final point, it will be useful for further studies to compare the results of this study in different sectors and regions such as Africa, Asia and Latin America to analyze the similarities and dissimilarities. 


\section{REFERENCES}

Ahadzie, D. K., Proverbs, D. G., Olomolaiye, P. O., \& Ankrah, N. (2009). Towards developing competencybased measures for project managers in mass house building projects in developing countries. Construction Management and Economics, 27(1), 89-102.

Anwar, M. R., Djakfar, L. D., \& Abdulhafidha, A. K. (2012). Human Resources Performance and Competency of Management by Using a Method of Balanced Scorecard. International Journal of Civil \& Environmental Engineering IJCEE-IJENS , 12(04), 01-05.

Asree, S., Zain, M., \& Razalli, M. R. (2010). Influence of leadership competency and organizational culture on responsiveness and performance of firms. International Journal of Contemporary Hospitality Management, 22(4), 500-516.

Baker, S. S., Pearson, M., \& Chipman, H. (2009). Development of Core Competencies for Paraprofessional Nutrition Educators Who Deliver Food Stamp Nutrition Education. Journal of Nutrition Education and Behavior , 41(2), 138-142.

Bilim, Sanayi ve Teknoloji Bakanligi. (n.d.). Bilim, Sanayi ve Teknoloji Bakanligi. Retrieved April 3, 2013, from http://www.sanayi.gov.tr/Files/Documents/TurkiyeSanayiStratejisiIngilizce.pdff

Boyatsiz, R.E. (2008), Competencies in the 21st century, Journal of Management Development, 27 (1), 5 12

Cardy, R. L., \& Selvarajan, T. (2006). Competencies: Alternative frameworks for competitive advantage. Business Horizons, 49, 235-245.

Clardy, A. (2008). Human Resource Development and the Resource-Based Model of Core Competencies: Methods for Diagnosis and Assessment. â€ , Human Resource Development Review, 7(4), 387-407.

Clark, J., \& Armit, K. (2010). Leadership competency for doctors: a framework. Leadership in Health Services, 23(2), 115-129.

Currie, G., \& Darby, R. (1995). Competence-based management development: rhetoric and reality. Journal of European Industrial Training, 19(5), 11-18.

Dainty, A. R., Cheng, M., \& Moore, D. R. (2004). A competency-based performance model for construction project managers. Construction Management and Economics, 22, 877-886.

Dess, G. G., Lumpkin, G. T., \& Eisner, A. B. (2010). Strategic Management. New York: McGraw Hill.

Dingle, J. (1995). Analyzing the competence requirements of managers. Management Development Review, 8(2), 30-36.

Draganidis, F., \& Mentzas, G. (2006). Competency based management: a review of systems and approaches. Information Management \&Computer Security, 14(1), 51-64.

Gammie, E., \& Joyce, Y. (2009). Competence-based Approaches to the Assessment of Professional Accountancy Training Work Experience Requirements: The ICAS Experience. Accounting Education, 18(4), 443-466.

Growth of the Service Sector. (2000, September 22). www.worldbank.org. Retrieved March 4, 2013, from www.worldbank.org/depweb/beyond/beyondco/beg_09.pdf

Kaya, N. (2006). The impact of human resource management practices and corporate entrepreneurship on firm performance: evidence from Turkish firms. The International Journal of Human Resource Management, 17(12), 2074-2090.

Kotler, P., \& Keller, K. L. (2009). Marketing management (13th ed.). Upper Saddle River, N.J.: Pearson Prentice Hall.

Levenson, A. R., Van der Stede, W. A., \& Cohen, S. G. (2009). Measuring the Relationship Between Managerial Competencies and Performance. Journal of Management, 32(3), 360-380. 
Liu, X., Ruan, D., \& Xu, Y. (2005). A study of enterprise human resource competence appraisement. Journal of Enterprise Information Management, 18(3), 289-315.

Mc Clelland, D. C. (1973). Testing for competence rather than for intelligence. American Psychologist, 28, 114.

Mitchell, L., \& Boak, G. (2009). Developing competence frameworks in UK healthcare: lessons from practice. Journal of European Industrial Training, 33(8/9), 701-717.

Pate, J., Martin, G., \& Robertson, M. (2003). Accrediting Competencies: a Case of Scottish Vocational Qualifications. Journal of European Industrial Training, 27(2-3-4), 169-176.

Pereira, C. M., \& Gomes, J. F. (2012). The strength of human resource practices and transformational leadership: impact on organizational performance. The International Journal of Human Resource Management, 20(23), 4301-4318.

Qiao, J. X., \& Wang, W. (2009). Managerial competencies for middle managers: some empirical findings from China. Journal of European Industrial Training, 33(1), 69-80.

Ryan, G., Emmerling, R. J., \& Spencer, L. M. (2009). Distinguishing high-performing European executives. Journal of Management Development, 28(9), 859-875.

Service Sector Definition | Investopedia. (n.d.). Investopedia - Educating the world about finance. Retrieved April 3, 2013, from http://www.investopedia.com/terms/s/service-sector.asp\#axzz2EgphA2kv

Soderquist, K. E., Papalexandris, A., Ioannou, G., \& Prastacos, G. (2010). From task-based tocompetencybased A typology and process supporting a critical HRM transition. Personnel Review, 39(3), 325-346.

Tereza, M., Fleury, L., Carlos, A., \& Fleury, C. (2005). In search of competence: aligning strategy and competences in the telecommunications industry. The International Journal of Human Resource Management, 16(9), 1640-1655.

Touron, M. M. (2009). Why a multinational company introduces a competency-based leadership model: a two-theory approach. The International Journal of Human Resource Management, 20(3), 606-632.

Triplett, J. E., \& Bosworth, B. (2004). Productivity in the U.S. services sector: new sources of economic growth. Washington, D.C.: Brookings Institution Press.

Vakola, M., Soderquist, K. E., \& Prastacos, G. P. (2007). Competency management in support of organisational change. International Journal of Manpower, 28(3/4), 260-275.

Qiao, J. X., \& Wang, W. (2009). Managerial competencies for middle managers: some empirical findings from China. Journal of European Industrial Training, 33(1), 69-80.

Ozcelik, G., \& Ferman, M. (2006). Competency Approach to Human Resources Management:Outcomes and Contributions in a Turkish Cultural Context. Human Resource Development Review, 5(1), 72-91. 